\title{
An improved procedure to assess the organic biodegradability and the biomethane potential of organic wastes for anaerobic digestion
}

\author{
R. Teixeira Franco ${ }^{1}$, Helen Coarita ${ }^{1}$, R. Bayard ${ }^{1}$, P. Buffière ${ }^{1}$ \\ ${ }^{1}$ Université de Lyon, INSA Lyon, DEEP Laboratory, EA7429, F-69621 Villeurbanne cedex, France
}

Corresponding author: remy.bayard@insa-lyon.fr; Tel.: +33(0) 472438753

\begin{abstract}
In this study a fractionation procedure was developed and applied to evaluate the potential of some organic wastes ( 2 cattle manures and 2 catch crops, fresh and after ensiling) for anaerobic digestion. This procedure was based on water extraction of the raw sample, which enabled to evaluate the contributions of watersoluble and particulate phases to the investigated properties. Biomethane potential (BMP) and chemical oxygen demand (COD) were determined and used to assess the anaerobic biodegradability of raw materials. Analysis of structural carbohydrates, total Kjeldahl nitrogen, water-soluble carbohydrates, volatile fatty acids and $\mathrm{pH}$ were also included to explain the main phenomena involved in methane production from the tested biomasses. Results show that the origin and the preparation mode had a significant impact on BMP distribution. Based on a COD balance, the biodegradability of the various feedstocks ranged from $45 \%$ to $75 \%$. Biodegradability of fresh materials was negatively correlated with the sum of structural carbohydrates and lignin content. Among the feedstock used, the water-soluble phase represented 8-69\% of the total COD and $7-46 \%$ to the total BMP. Solubilization of organic matter during ensiling was due to the production and accumulation of organic acids from particulate carbohydrates and organic nitrogen. This procedure detects kinetic and biodegradability differences among biomasses and thus it can be useful for the design of anaerobic digestion plants. Furthermore, it can be applied to evaluate the efficiency of biomass pretreatments.
\end{abstract}


Keywords: Anaerobic digestion, Organic wastes, Biomass characterization, Organic matter leaching, Biodegradability, Biomethane production, Biodegradability rate, Methane yield.

\section{Introduction}

Over the last decades, anaerobic digestion (AD) has become an outstanding alternative to produce green energy. This process is a seductive solution not only for the treatment of agricultural and agro-industrial organic waste, but also for the management of municipal wastewater sludge, residual or source-sorted municipal solid waste. In this context, AD answers to two complementary issues: the treatment of organic waste, as well as the production of renewable energy. Biogas and biomethane are produced by biological pathway of methanogenesis. Without oxygen, biomass is hydrolyzed and monomers converted to water, carbon dioxide and methane. Thereafter, biogas can be used in combined heat and power (CHP) to produce energy and electricity, or purified and upgraded as biomethane for injection in urban natural gas grid, or used as biofuel for vehicles. For farm-scale digesters, the solid residues are generally post-treated for drying and composting, and used as organic amendment. Due to the diversity of feedstocks that can be used for biogas production, there is a growing interest in developing characterization procedures to assess their potential and suitability (Carlsson et al., 2012; Kianmehr et al., 2010; Montgomery and Bochmann, 2014). Moreover, these feedstocks undergo different stages, or unit operation, before entering the AD reactor, such as storage and pretreatments. Optimizing these steps requires an adequate characterization of their effect, including detailed data on specific properties such as methane yield, biochemical composition and biodegradability.

A large variety of substrates and organic residues may, therefore, be treated by anaerobic digestion (AD), including agricultural waste and green waste, sludge from wastewater treatment, source-sorted biowaste or residual municipal solid waste, food and food-processing waste (Bayard et al., 2016). The most common parameter for characterization is the biomethane potential (BMP), which corresponds to the amount of 
methane produced per mass unit of total solids (TS) or volatile solids (VS). Nevertheless, BMP is not enough to predict the degradation rate in AD process (Bayard et al., 2018; Schievano et al., 2008; Xu et al., 2014). Many experimental studies have been conducted to correlate BMP and biochemical characteristics of organic substrates. Among these, lignin content is known to be negatively correlated with anaerobic biodegradability (BMP) (Buffiere et al., 2008, 2006; Liu et al., 2015; Triolo et al., 2012). Under process conditions, biomass conversion to methane strongly depends on the accessibility of organic compounds to external enzymes (Jeffries, 1994, 1990; Jimenez et al., 2015). Indeed, hydrolysis of particulate matter is considered as the rate-limiting step during anaerobic digestion of solid organic substrates, and its intensification leads to a better digestion performance (Shin et al., 2001; Tanaka et al., 1997; Vavilin et al., 1996). Organic compounds such as cellulose, lignin, cutin or keratin are slowly or nonbiodegradable compounds under anaerobic conditions while polymers such as starch and hemicellulose are assumed to be more readily biodegradable. Moreover, some biodegradable compounds may be less available since they are incorporated into complex, hardly biodegradable structures, such as lignocellulose or microbial cells (Gonzalez-Estrella et al., 2017; Jeffries, 1994, 1990; Patinvoh et al., 2017).

Biomass storage before anaerobic digestion is also an issue: the wide diversification of AD inputs and the need for continuous feeding of $\mathrm{AD}$ plants throughout the year make necessary to store collected agricultural/industrial waste or catch/energy crops for prolonged period (Teixeira Franco et al., 2016a). The nature of the feedstock, the presence of air and the duration are the main parameters for the success of the long term storage (McDonald et al., 1991). Regarding BMP conservation, ensiling (or confined storage) is a good solution to store wet biomass (Teixeira Franco et al., 2017a, 2017b).

Pre-treatment processes have been developed over the last three decades to improve methane production in AD plants. Several reviews have recently been published with full description of pre-treatment technologies (Ariunbaatar et al., 2014; Carlsson et al., 2012; Carrere et al., 2016; Elliott and Mahmood, 2012; Hendriks and Zeeman, 2009; Montgomery and Bochmann, 2014; Paudel et al., 2017). It is well established that the 
expected effects are i) the improvement of the methane yield and ii) the improvement of the methane production rate. As reviewed by Carlsson et al. (2012), the main targeted effects of pre-treatment are particle size reduction, solubilisation, and biodegradability enhancement. For instance, mechanical pretreatments are commonly used for the reduction of particle size, and increase substrate surface (Hartmann et al., 2000; Tsapekos et al., 2015; Vavilin et al., 1996). Combination of grinding, milling and chipping can significantly increase the methane yield because organic compounds become more available to enzymatic hydrolysis (Vavilin et al., 1996; Ward et al., 2008). In addition, the efficiency of pre-treatments can be highly different depending on the characteristics of the substrates and of the pre-treatment parameters (Ariunbaatar et al., 2014). Moreover, it is difficult establish a systematic comparison of the effects of a given pre-treatment. The main reasons for this are the diversity of substrates and the lack of common/standardized protocols for the evaluation (Carlsson et al., 2012; Kianmehr et al., 2010).

In the present work, an improved fractionation procedure is proposed to explain more in details the distribution of biodegradability and the methane yield (BMP) of feedstocks for anaerobic digestion. This procedure was complemented with the analysis of chemical oxygen demand (COD), structural carbohydrates, total Kjeldahl nitrogen (TKN), water-soluble carbohydrates (WSC), volatile fatty acids (VFA) and pH. Additionally, the monitoring of both water-soluble and particulate fractions of the different studied properties was performed, which is another originality of this study. Trials were carried out with two different types of catch crops and cattle manures. Nevertheless, this procedure should be suitable for other types of biomass, such as energy crops or urban organic waste, and appropriate to study storage conditions and the effect of substrate pretreatment on AD. The main aim of this work is to provide a useful tool to evaluate potential inputs for $\mathrm{AD}$ and to optimize the design of biogas plants. For this purpose, several agricultural fresh and ensiled feedstocks are been selected to design and test the fractionation procedure.

\section{Material and methods}




\section{$\underline{\text { Raw materials }}$}

Two different types of catch crop and fresh cattle manure were collected from an agricultural site near Lyon (France). These feedstocks were chosen due to its major relevance in farm-scale AD, especially in France. Catch crop 1 (CC1) was a mixture of triticale, peas, vicia and fodder radish, and it was chopped at $4 \mathrm{~cm}$ maximum length at harvesting. Catch crop 2 (CC2) was a mixture of sunflower, sorghum, peas, vicia and Trifolium alexandrinum, and it was shredded with a BLIK BB350 rotary shear crusher before use (8 mm output particle size according to the manufacturer). Cattle manure 1 (M1) and Cattle manure 2 (M2) were collected from the same site but on different seasons of the year (March and October, respectively). Samples were stored at $4^{\circ} \mathrm{C}$ before further use.

The characterization procedure described in this work was applied to both fresh and ensiled raw materials. Confined storage (ensiling) was performed at $25 \pm 2{ }^{\circ} \mathrm{C}$ in $3.5 \mathrm{~L}$ airtight round plastic storage drums during 3 months for catch crops and 4 months for cattle manure. Nomenclature and description of feedstocks are summarized in Table 1. Ensiling was tested for several reasons. First, it is a common practice for storage of herbaceous AD feedstocks (catch and energy crops). Since several biological phenomena occur during ensiling, biochemical properties may be extensively modified with biomass storage. In some cases, ensiling can be even considered as a biological pretreatment due to its positive impact on the methane potential of stored feedstocks (Janke et al., 2019; Vervaeren et al., 2010). Therefore, by testing ensiled feedstocks, we assess the applicability of the proposed analytical procedure to feedstocks with different biochemical properties, management practices and pretreatments before AD.

Moreover, at field scale, manure is rather stored in an open-air mode, which leads to considerable loss of organic matter and BMP (Teixeira Franco et al., 2018b, 2017b). By storing manure under confined conditions, the objective was to evaluate if its BMP could be more efficiently preserved (for simplicity, confined conditions are referred to as "ensiling" in the present paper). It has to be mentioned however that 
the evolution of the total mass, TS, VS, BMP during the ensiling process were also measured for all the experiments. Since the impact of the ensiling conditions on the global efficiency of the process have been investigated in details (Teixeira Franco et al., 2016b, 2017a, 2017b, 2018a), the present paper will rather focus on the interest of the proposed experimental procedure.

Table 1 Nomenclature and properties of raw materials

\begin{tabular}{cccccc}
\hline Biomass & Preparation & Nomenclature & TS (\%) & VS (\% TS) & pH \\
\hline \multirow{2}{*}{ Catch crop 1 } & Fresh & CC1-F & $18.2 \pm 0.3$ & $89.2 \pm 0.7$ & 7.20 \\
& Ensiled & CC1-E & $16.8 \pm 0.3$ & $90.0 \pm 0.4$ & 5.41 \\
\hline \multirow{2}{*}{ Catch crop 2 } & Fresh & CC2-F & $10.1 \pm 0.13$ & $83.5 \pm 1.4$ & 6.35 \\
& Ensiled & CC2-E & $8.10 \pm 0.3$ & $78.9 \pm 4.1$ & 5.59 \\
\hline \multirow{2}{*}{ Cattle manure 1 } & Fresh & M1-F & $12.8 \pm 0.07$ & $79.9 \pm 0.17$ & 7.94 \\
& Ensiled & M1-E & $9.12 \pm 0.08$ & $70.6 \pm 0.10$ & 8.40 \\
\hline \multirow{2}{*}{ Cattle manure 2 } & Fresh & M2-F & $11.6 \pm 0.12$ & $82.2 \pm 0.20$ & 7.70 \\
& Ensiled & M2-E & $9.34 \pm 0.12$ & $77.4 \pm 0.04$ & 7.82 \\
\hline
\end{tabular}

Experimental procedure and chemical analysis

The developed fractionation procedure (Erreur ! Source du renvoi introuvable.) was based on water extraction of the raw sample (leaching test), separation and analysis of its different fractions. Leaching test is based on the NF EN 12457-4 (AFNOR, 2002) and it was performed with a standard 10:1 water/TS ratio during $2 \mathrm{~h}$ under constant bottle rotation at room temperature. Phase separation was done by centrifugation ( $5000 \mathrm{G} ; 10 \mathrm{~min}$ ), followed by $0.7 \mathrm{~mm}$ particle size filtration. Finally, the particulate phase was dried at 70 ${ }^{\circ} \mathrm{C}$ until constant weight, and grounded with a Retsch SM 200 cutting mill and a bottom sieve with an aperture size of $2 \mathrm{~mm}$. Raw and water-soluble samples were stored at $4{ }^{\circ} \mathrm{C}$ until analysis and particulate ones were stored at and $-20^{\circ} \mathrm{C}$. 
Raw sample (RS) was analyzed for its TS, VS and BMP. For the water-soluble phase, besides TS, VS and BMP, $\mathrm{pH}$, WSC, VFA, COD, TKN, and ammonia nitrogen $\left(\mathrm{NH}_{3}-\mathrm{N}\right)$ fractions were determined. Particulate solid was analyzed for its TS, VS, COD, TKN, and cell wall constituents. In order to assess the distribution of the various components of interest, some properties were determined through mass balances. For instance, the BMP of the particulate phase $\left(L_{S T P} / \mathrm{kgVS}_{R S}\right)$ was estimated as the difference between the $\mathrm{BMP}$ of the raw material and the BMP of the water-soluble phase $\left(L_{S T P} / k g V S_{R S}\right)$. On the other hand, COD and TKN of the raw sample were estimated as the sum of the water-soluble and particulate contributions (both expressed in $\mathrm{kg} / \mathrm{kgVS} S_{R S}$ ).

The biodegradability (BD) of each fraction was calculated from BMP and COD values considering the theoretical BMP of $0.35 \mathrm{~L}_{\mathrm{STP}} / \mathrm{kg}_{\mathrm{COD}}$ ( Buswell and Mueller, 1952):

$$
B D(\%)=\frac{B M P\left[L_{S T P} / k g V S\right]}{C O D[k g / k g V S] \times 0.35}
$$




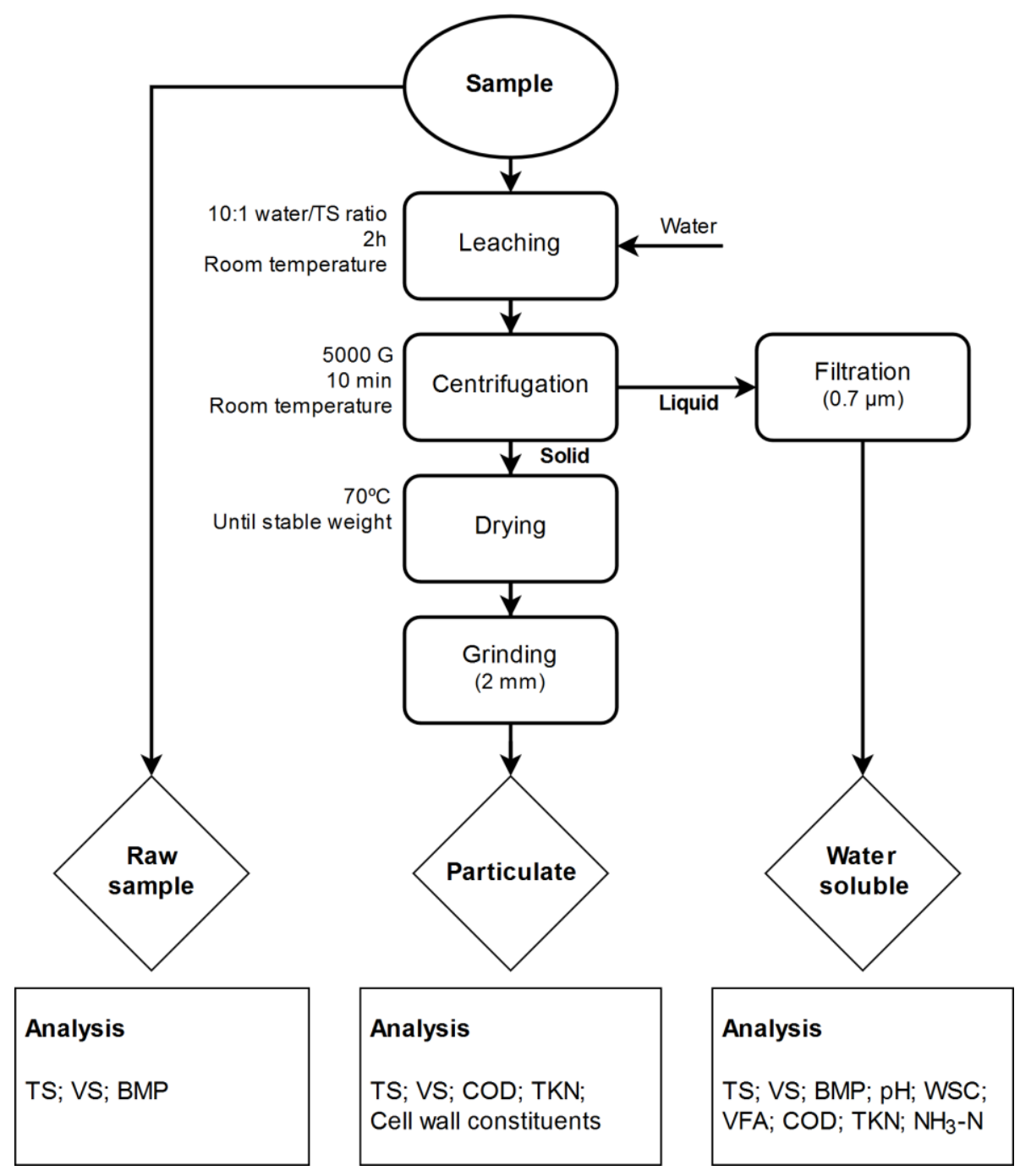

Fig. 1 Flowchart of the experimental methodology

TS was measured by oven drying at $105{ }^{\circ} \mathrm{C}$ during $24 \mathrm{~h}$ and VS was subsequently burned for $2 \mathrm{~h}$ at $550{ }^{\circ} \mathrm{C}$. Since TS and VS contents are underestimated due to the loss of volatile compounds during the drying tests (Kreuger et al., 2011), data was corrected according to the volatilization coefficients at $100{ }^{\circ} \mathrm{C}$ (Porter and Murray, 2001). pH was measured by a Consort C3020 device with a SP10B pH-electrode. WSC, lactic acid and formic acid contents were determined with high performance liquid chromatography (LC Module 1 
plus, Waters) equipped with a Supelcogel ${ }^{\mathrm{TM}} \mathrm{C}-610 \mathrm{H}$ column $(300$ x $7.8 \mathrm{~mm}$, Sigma-Aldrich), both refractive index (RID) and UV detectors and operating with $\mathrm{H}_{3} \mathrm{PO}_{4} 0.1 \% \mathrm{v}$ as solvent (flow rate of 0.5 $\mathrm{mL} / \mathrm{min}$ ). WSC content was estimated as the sum of glucose, xylose, galactose, mannose, arabinose and cellobiose and it was determined using the RID detector. Lactic acid and formic acid contents were obtained with the UV detector (210 nm). Acetic, propionic, butyric, valeric and caproic acids content were analyzed by gas chromatography (Shimadzu Corp.) equipped with a HP-FFAP fused silica capillary column (30 m x $0.25 \mathrm{~mm}$, Agilent Technologies), a flame ionization detector and using $\mathrm{H}_{2}$ as carrier gas. Total VFA was calculated as the sum of lactic, formic, acetic, propionic, butyric, valeric and caproic acids. TKN and $\mathrm{NH}_{3}^{-}$ $\mathrm{N}$ were determined through the procedure described in the NF EN 25663 standard (AFNOR, 1994). COD of water-soluble phase was determined through the colorimetric HACH procedure (method 8000). COD of particulate phase was measured by the Walkley and Black (1934) modified method, based on the NF ISO 14235 international standard (ISO, 1998). Neutral detergent fibre (NDF), acid detergent fibre (ADF) and acid detergent lignin (ADL) were analysed through Van Soest and Wine (1967) modified extractions method based on FD U44-162 standard (AFNOR, 2016). It was conducted on aliquots of powdered dry samples corresponding to $2 \mathrm{~g}$ of volatile solids. At each step, the residual solids were dried and weighed and analysed for VS contents. Four types of organic constituents were quantified, namely: (1) neutral detergent soluble compounds (SOL) extracted at the first step by a neutral detergent aqueous solution (NDF); (2) Hemicelluloses-like (HEM) extracted with a dilute acidic aqueous detergent solution, calculated as NDF minus ADF; (3) Cellulose-like (CELL) extracted with a concentrated $72 \%$ sulfuric acid solution, calculated as ADF minus ADL; and (4) lignin-like residual organic matter (LIG) which was not extracted in the procedure, corresponding to ADL.

The BMP tests followed the guidelines provided by the international working group on harmonization of BMP measurement (Holliger et al., 2016). They were conducted at $35^{\circ} \mathrm{C}$ using glass vessels of $2 \mathrm{~L}$ for raw sample, in order to ensure sample representativity, and $0.1 \mathrm{~L}$ for water-soluble phase in order to limit the 
amount of sample needed. Vessels were filled with $5 \mathrm{~g} / \mathrm{L}$ VS of sample, and $10 \mathrm{gL}$ VS inoculum (inoculum/subrate $=2$ ) and a sufficient volume of a mineral solution to achieve $60 \%$ of the total volume of the vessel. The inoculum used (TS 2.0-3.3\%wt; VS 1.4-2.2\%wt) was a digested sludge originating from the wastewater treatment plant of La Feyssine, Lyon, France. The mineral solution, which contains essential elements for microbial growth and also gives the solution a buffer able to control any $\mathrm{pH}$ adjustments, was prepared according to the recommendations of ISO 11734:1995 standard (ISO, 1995). Once filled, reactors were purged with a $\mathrm{N}_{2} / \mathrm{CO}_{2}$ mixture $\left(80 / 20 \%\right.$ v) for about 5 minutes, sealed and equilibrated at $35^{\circ} \mathrm{C}$. Blanks with inoculum and mineral solution were performed for each batch series in order to correct the BMP from residual methane production of the inoculum. All tests were performed in triplicates. Biogas production was determined by pressure measurement using a Digitron precision manometer. Biogas was released when the pressure exceeded $1200 \mathrm{hPa}$. Gas composition $\left(\mathrm{CH}_{4}, \mathrm{H}_{2}, \mathrm{~N}_{2}, \mathrm{O}_{2}, \mathrm{H}_{2} \mathrm{O}\right.$ and $\left.\mathrm{H}_{2} \mathrm{~S}\right)$ was analysed using an Agilent 3000 micro gas chromatography with thermal conductivity detector (GC-TCD). Molsieve 5A (14 m length; pore size: $5 \AA$ ) and PoraPlot A (10 m length; $0.320 \mathrm{~mm}$ ID) columns were used as stationary phases for GC-TCD, with Argon and Helium as carrier gases, respectively. According to the guidelines, BMP was considered achieved when daily biogas production represented less than $1 \%$ of the total volume of biogas produced.

\section{Results and discussion}

Distribution of methane yield (BMP) and biodegradability (BD)

The BMP values varied widely within the set of tested raw materials (Table 2). Fresh catch crops had a BMP of 210-335 $\mathrm{L}_{\mathrm{STP}} / \mathrm{kgVS} \mathrm{RS}_{\mathrm{RS}}$, while BMP of fresh cattle manures was $257-288 \mathrm{~L}_{\mathrm{STP}} / \mathrm{kgVS} \mathrm{SR}_{\mathrm{RS}}$. The preparation mode also had an impact on the BMP of the feedstocks. Ensiling had a positive effect on the methane production of catch crops. On the contrary, BMP of cattle manure decreased after long-term ensiling. This reflects the relevance of controlling storage and preparation of inputs before biogas 
production. Also, it is worth mentioning that BMP of ensiled biomass may be overestimated, since organic losses during storage are not taken into account.

Table 2 Biomethane potential of feedstocks and its phase distribution

\begin{tabular}{|c|c|c|c|c|c|c|c|c|}
\hline & CC1-F & CC1-E & CC2-F & CC2-E & M1-F & M1-E & M2-F & M2-E \\
\hline \multicolumn{9}{|c|}{ Raw sample } \\
\hline $\begin{array}{c}\text { BMP } \\
\left(\mathrm{L}_{\mathrm{STP}} / \mathrm{kgVS}_{\mathrm{RS}}\right)\end{array}$ & $210 \pm 14$ & $300 \pm 12$ & $335 \pm 34$ & $410 \pm 7$ & $288 \pm 14$ & $255 \pm 7$ & $257 \pm 6$ & $217 \pm 2$ \\
\hline \multicolumn{9}{|c|}{ Water-soluble phase } \\
\hline $\begin{array}{c}\text { BMP } \\
\left(\mathrm{L}_{\mathrm{STP}} / \mathrm{kgVS}_{\mathrm{RS}}\right)\end{array}$ & $20 \pm 0.6$ & $72 \pm 5.0$ & $41 \pm 2.3$ & $190 \pm 28$ & $77 \pm 1.1$ & $38 \pm 0.3$ & $43 \pm 4.0$ & $48 \pm 1.8$ \\
\hline$\% \mathrm{BMP}_{\mathrm{RS}}$ & 7.3 & 24.1 & 12.3 & 46.3 & 26.9 & 15.1 & 16.6 & 22.2 \\
\hline \multicolumn{9}{|c|}{ Particulate phase } \\
\hline $\begin{array}{c}\text { BMP } \\
\left(\mathrm{L}_{\mathrm{STP}} / \mathrm{kgVS}_{\mathrm{RS}}\right)\end{array}$ & $250 \pm 20$ & $228 \pm 24$ & $294 \pm 46$ & $220 \pm 37$ & $210 \pm 13$ & $217 \pm 8$ & $215 \pm 27$ & $169 \pm 8$ \\
\hline$\% \mathrm{BMP}_{\mathrm{RS}}$ & 92.7 & 75.9 & 87.7 & 53.7 & 73.1 & 84.9 & 83.4 & 77.8 \\
\hline
\end{tabular}

Likewise, distinct distributions of BMP were found among the feedstocks. Indeed, contribution of watersoluble phase to the BMP of the raw sample ranged from $7 \%$ to $46 \%$. For catch crops, the ensiling process leads to a general increase of the contribution of the soluble fraction to the total BMP (from 7.3 to $24.1 \%$ and from 12.3 to $46.3 \%$ for $\mathrm{CC} 1$ and $\mathrm{CC} 2$ respectively). The water-soluble phase mostly contains nonlignocellulosic and simple compounds that can be transformed in methane afterwards, including different types of water-soluble carbohydrates, volatile fatty acids, or even soluble amino acids. These soluble compounds are more quickly converted into methane than particulate ones (Pavlostathis and GiraldoGomez, 1991; Shrestha et al., 2017). Therefore, feedstocks with higher contribution of water-soluble phase to the BMP will theoretically have a faster degradation during $\mathrm{AD}$, as will be discussed later. In addition, soluble compounds are more easily diffused into the reactor, improving feedstock's accessibility to the degrading microorganisms. Therefore, the analysis of BMP distribution provides crucial information 
concerning degradation kinetics, which is essential for feedstock selection, pretreatment operation, and design of $\mathrm{AD}$ plants.

Moreover, the distribution of BMP was affected by ensiling, demonstrating that management practices of feedstocks before AD may have a significant influence on organic matter structure. On the one hand, for catch crops the contribution of water-soluble phase to the BMP increased with ensiling. This may be explained by the hydrolysis of complex carbohydrates/proteins and their subsequent accumulation in the form VFA after lactic fermentation. These are well documented phenomena in good quality silages (at low pH conditions) (Desta et al., 2016; McDonald et al., 1991; Menardo et al., 2015; Pakarinen et al., 2011; Teixeira Franco et al., 2017a). On the other hand, while testing cattle manure it is difficult to distinguish a specific impact of confined storage on the phase distribution of BMP. This is attributed to the fact that manure evolves differently during storage and it is highly degraded due to its inadequate conservation properties (lack of WSC, high buffering capacity, etc.) (Teixeira Franco et al., 2018b, 2018a, 2017b).

It should be noticed that ensiling is sometimes considered as long-term biological pretreatment due to its impact on BMP and biomass properties (Ambye-Jensen et al., 2013; Gallegos et al., 2017; Larsen et al., 2017; Teixeira Franco et al., 2016a). Thus, these results suggest that this type of multiphase analysis may also provide important data on the efficiency of various pretreatments, either concerning the solubilization of organic matter or the improvement of degradation kinetics.

From the collected data on BMP tests, it is possible to evaluate the individual methane production kinetics between the raw and soluble fraction of a given sample. In all our tests, the methane production (after deduction of inoculum methane production) was well represented by a $1^{\text {st }}$ order kinetics. The interesting output was that for all the dataset presented, the $1^{\text {st }}$ order constant $k$ ranged from 0.1 to $0.18 \mathrm{~d}^{-1}$ for raw samples, and from 0.25 to $0.39 \mathrm{~d}^{-1}$ for the soluble fraction. However, the comparison of the BMP kinetics for long-term tests like ensiling is subject to doubts, since the anaerobic inoculum used for the BMP tests 
would probably not have a similar activity. In other word, it is advised to use the same inoculum to compare the effect of a given pre-treatment on the BMP production kinetics (Buffière et al., 2018).

\section{COD balance}

The results of COD analysis and its phase distribution are shown in Table 3. COD of raw sample was 1204$1553 \mathrm{~g} / \mathrm{kgVS}_{\mathrm{RS}}$ for the tested feedstocks.

Table 3 Chemical oxygen demand of feedstocks and its phase distribution. WSC and VFA contents (COD basis) are presented in the water-soluble phase

\begin{tabular}{|c|c|c|c|c|c|c|c|c|}
\hline & CC1-F & CC1-E & CC2-F & CC2-E & M1-F & M1-E & M2-F & M2-E \\
\hline \multicolumn{9}{|c|}{ Raw sample } \\
\hline $\begin{array}{c}\mathrm{COD} \\
\left(\mathrm{g}_{\mathrm{O} 2} / \mathrm{kgVS}_{\mathrm{RS}}\right)\end{array}$ & 1280 & 1527 & 1296 & 1553 & 1476 & 1204 & 1314 & 1310 \\
\hline \multicolumn{9}{|c|}{ Water-soluble phase } \\
\hline $\begin{array}{c}\mathrm{COD} \\
\left(\mathrm{g}_{\mathrm{O} 2} / \mathrm{kgVS}_{\mathrm{RS}}\right)\end{array}$ & 100 & 464 & 184 & 1074 & 275 & 146 & 133 & 183 \\
\hline$\% \mathrm{COD}_{\mathrm{RS}}$ & 7.8 & 30.4 & 14.2 & 69.2 & 18.6 & 12.1 & 10.2 & 14.0 \\
\hline $\begin{array}{c}\text { WSC } \\
\left(\% \mathrm{COD}_{\mathrm{RS}}\right)\end{array}$ & 0.10 & 0.11 & 9.90 & 0.09 & 0.00 & 0.00 & 0.00 & 0.16 \\
\hline $\begin{array}{c}\text { VFA } \\
\left(\% \mathrm{COD}_{\mathrm{RS}}\right)\end{array}$ & 3.1 & 16.0 & 0.72 & 18.3 & 2.2 & 2.3 & 5.8 & 10.6 \\
\hline \multicolumn{9}{|c|}{ Particulate phase } \\
\hline $\begin{array}{c}\mathrm{COD} \\
\left(\mathrm{g}_{\mathrm{O} 2} / \mathrm{kgVS}_{\mathrm{RS}}\right)\end{array}$ & 1180 & 1063 & 1112 & 479 & 1201 & 1058 & 1181 & 1127 \\
\hline$\% \mathrm{COD}_{\mathrm{RS}}$ & 92.2 & 69.6 & 85.8 & 30.8 & 81.4 & 87.9 & 89.8 & 86.0 \\
\hline
\end{tabular}

However, as for the methane potential, COD distribution varied greatly depending on the feedstock. The COD of the water-soluble phase was $100-1074 \mathrm{~g} / \mathrm{kgVS}_{\mathrm{RS}}$, which represents a contribution to the total COD of 8-69\%. Ensiled catch crops have the highest water-soluble COD. In fact, for these feedstocks there was 
a vast production and accumulation of VFA during ensiling. Likewise, VFA content increased during ensiling of Cattle Manure 2 (M2). In such cases, VFA produced during ensiling were far larger than initial WSC (even neglecting COD yield of endogenous bacteria). This means that part of VFA was a product of the hydrolysis (and fermentation) of particulate organic matter, as previously suggested.

It should be mentioned that it was not possible to establish a fully detailed COD balance of the watersoluble phase. In fact, the measured WSC and VFA accounted for $12 \%$ to $77 \%$ of the total water-soluble COD. The analysis of other compounds, such as alcohols, oligosaccharides or soluble amino acids, should be carried out in order to improve the description of the water-soluble COD.

\section{$\underline{\text { Structural carbohydrates and TKN balance }}$}

Table 4 shows a mass balance of the organic matter with a focus on the particulate fraction determined from the Van Soest analysis (on a VS basis of the raw sample since the COD of the lignocellulosic fractions are not known).

Table 4 VS balance of feedstocks, with a focus on the particulate organic matter and structural carbohydrates. Results are expressed on \%VS

\begin{tabular}{|c|c|c|c|c|c|c|c|c|c|}
\hline & & CC1-F & CC1-E & CC2-F & CC2-E & M1-F & M1-E & M2-F & M2-E \\
\hline \multicolumn{2}{|c|}{ Water-Soluble } & 8.6 & 25.7 & 15.6 & 68.5 & 18.0 & 19.5 & 16.6 & 22.2 \\
\hline \multirow{4}{*}{ Particulate } & SOL & 19.7 & 20.0 & 49.0 & 16.9 & 16.5 & 14.6 & 20.7 & 23.3 \\
\hline & HEM & 13.2 & 9.5 & 11.3 & 2.6 & 32.5 & 27.7 & 28.4 & 22.4 \\
\hline & CEL & 40.2 & 33.4 & 20.4 & 9.8 & 26.8 & 28.0 & 25.7 & 21.4 \\
\hline & LIG & 18.2 & 11.4 & 3.8 & 2.1 & 6.1 & 10.1 & 8.5 & 11 \\
\hline
\end{tabular}


Besides, the structure of organic matter strongly depends on either if the biomass is conserved through ensiling or not. Indeed, for all feedstocks there was a decrease of the lignocellulosic fraction during ensiling. According to previous works, this degradation is due to the enzymatic or acid hydrolysis that may occur during biomass preservation (Dewar et al., 1963; McDonald et al., 1991). Moreover, the degradation products of these reactions should be water-soluble compounds, since no increase of the non-structural particulate fraction (SOL) was recorded with ensiling.

$\mathrm{TKN}$ of raw samples varied from $25.8 \mathrm{~g} / \mathrm{kgVS}$ to $84.1 \mathrm{~g} / \mathrm{kgVS}$ (results not shown) and no correlation was found either for the type of biomass or the mode of preparation. This evidenced a great variability of the protein and amino acids content among organic wastes.

Furthermore, TKN composition clearly depended on the nature of the feedstock, as illustrated in Fig. 2. First, TKN was mostly present in the form organic nitrogen (soluble and particulate) for fresh materials. This was especially true for catch crops, in which ammonia content was less than 7\% of raw sample TKN. For fresh manures, ammonia nitrogen was $21-32 \%$ of raw sample TKN. The presence of ammonia is an indicator of biomass (protein) hydrolysis (McDonald et al., 1991; Teixeira Franco et al., 2016a) and may lead to bacterial inhibition (Batstone et al., 2002; Chen et al., 2014; Yenigün and Demirel, 2013). This issue should be more significant for the operation of digesters using cattle manure, since its low level of VFA may not contribute to mitigate the effects of $\mathrm{NH}_{3}$ on the $\mathrm{pH}$.

Likewise, ensiling had a marked impact on the distribution of nitrogen between the fractions. The particulate fraction of TKN decreased with ensiling, especially for catch crops. This was attributed to the slow hydrolysis of protein during storage, followed by a subsequent fermentation of amino acids, producing a pool of VFA, $\mathrm{H}_{2}$ and ammonia nitrogen (Batstone et al., 2002; McDonald et al., 1991). In summary, this fractionation procedure enabled to show that not only structural carbohydrates but also proteins and amino 
acids are degraded during the storage before AD. All these results clarify the solubilization of COD and BMP observed for some raw materials.

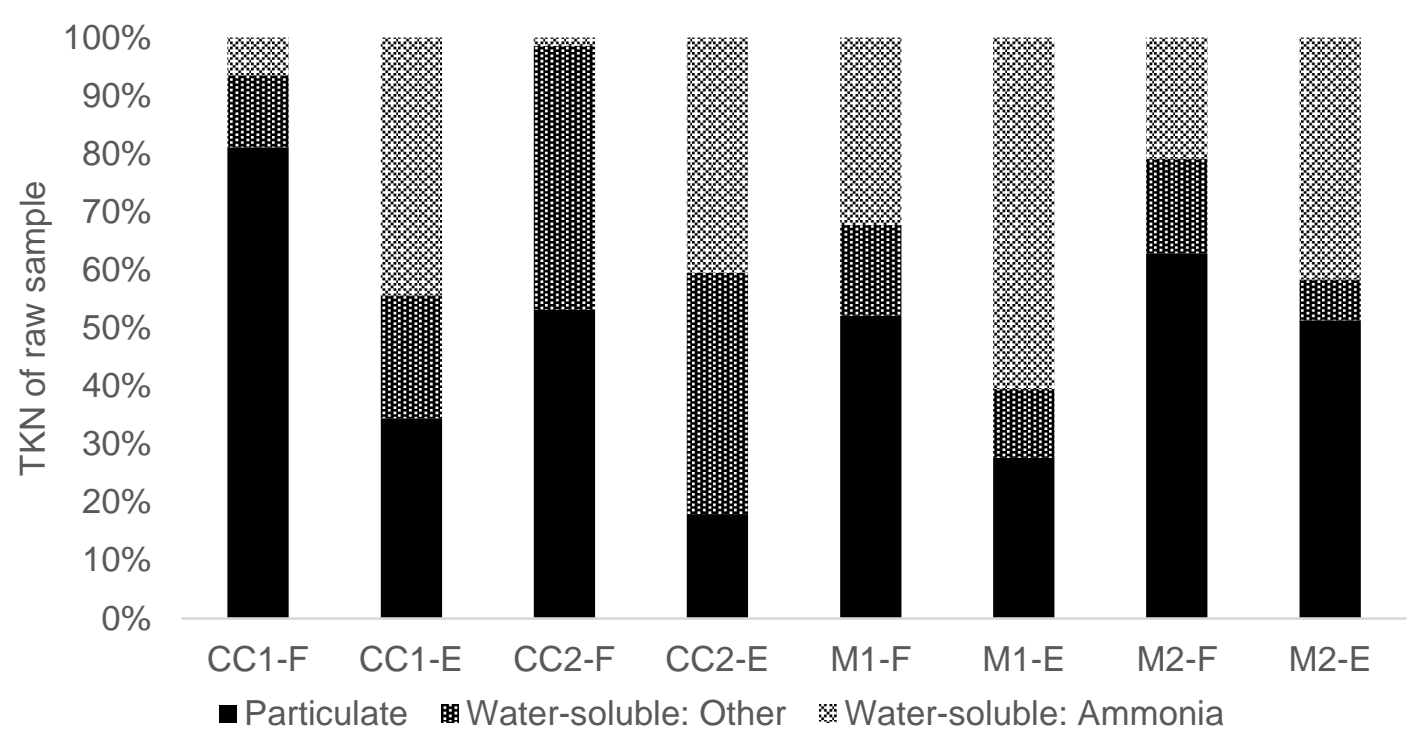

Fig. 2 TKN balance of feedstocks

\section{Organic biodegradability}

The impact of the results discussed above on the biodegradability of organic matter is shown in Fig. 3. It presents the different biodegradable (BD) and non-biodegradable (NDB) contributions of water-soluble and particulate fractions to the COD of the raw sample.

Total biodegradability varied among the fresh feedstocks: it was $47 \%$ for CC1-F, $74 \%$ for CC2-F and $56 \%$ for both M1-F and M2-F. From the VS balance presented in Table 4, biodegradability of fresh materials was negatively correlated with the sum of structural carbohydrates and lignin content. This is in agreement with previous studies that have demonstrate a negative impact of lignin content on methane production by anaerobic digestion (Buffiere et al., 2006; Jeffries, 1994; Liu et al., 2015; Triolo et al., 2011). 
On the one hand, the biodegradability of the particulate COD fraction was $59 \%$ in average. The nonbiodegradable (NBD) fraction corresponded to the lignocellulosic compounds that are not degraded during the BMP tests (Jeffries, 1994), and to the COD used for bacterial growth (biomass yield), which is a small amount. The biodegradability of the particulate phase was closely linked to the lignin content. On the other hand, the biodegradability of water-soluble phase was $65 \%$ in average. It is unlikely that all water-soluble NBD corresponds to the COD used for bacterial growth (the biomass yields suggested in the Anaerobic Digestion Model 1 is around 10\% on a COD basis (Batstone et al., 2002). Therefore, this suggests that an important part of the organic matter present in the water-soluble phase is not biodegradable, which was unexpected.

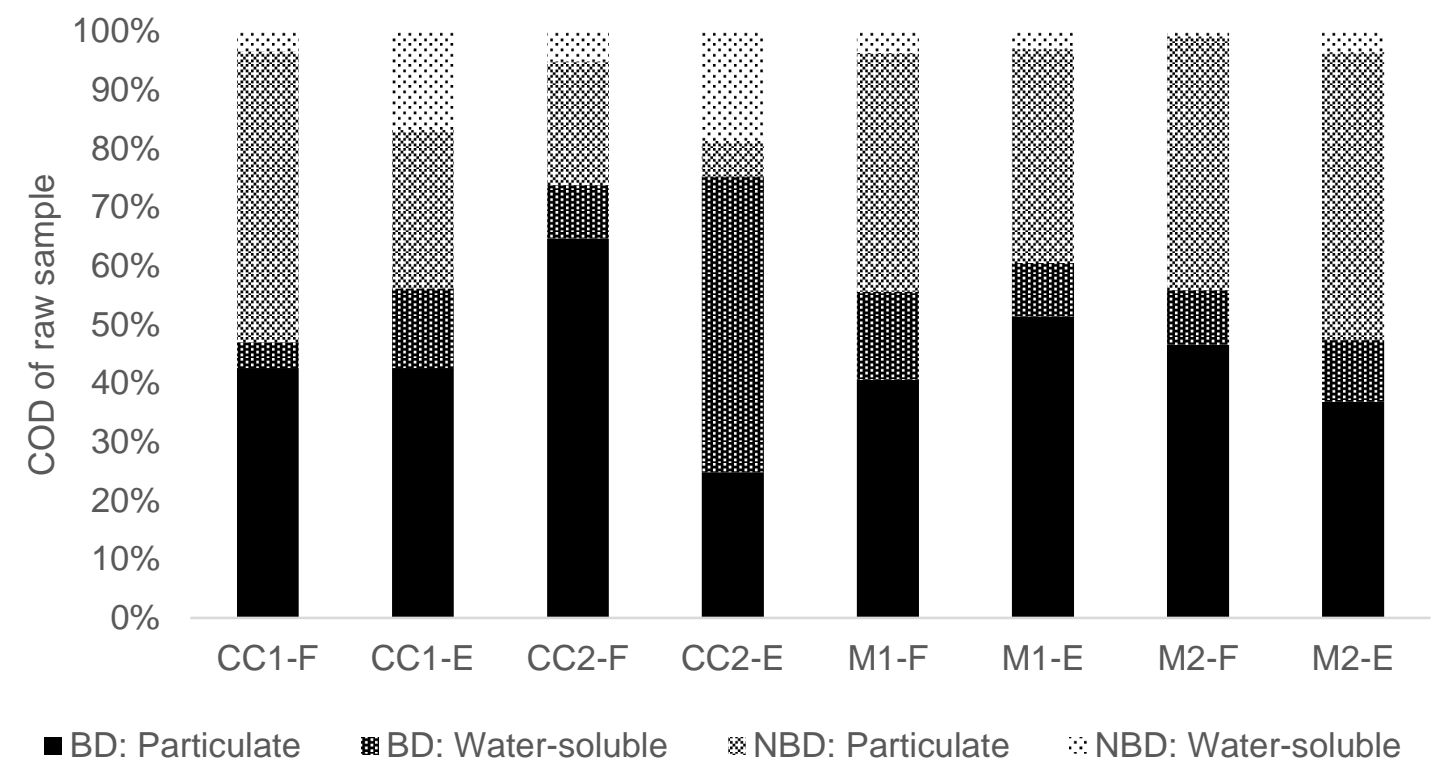

Fig. 3 Organic biodegradability of feedstocks and its phase distribution on a COD basis. BD stands for biodegradable; NBD stands for non-biodegradable

Finally, considerable differences in biodegradability were found for some feedstocks before and after ensiling. This was especially true for Catch Crop 1 and Cattle Manure 2. In the case of CC1, ensiling had a 
positive impact on biodegradability $(+19 \%)$. On the contrary, biodegradability of M2-E was $19 \%$ lower than that of M2-F. This demonstrates how the efficiency of biomass management before AD is important to safeguard the energetic content of organic matter as well as its biodegradability.

\section{Conclusions}

A fractionation procedure based on the separation of a water soluble and a particulate fraction was successfully applied to assess and explain the organic biodegradability and the biomethane potential of different catch crops and cattle manures. This procedure evidenced a significant impact of the origin of biomass and its management conditions on the BMP and the biodegradability rates. Furthermore, biodegradability of fresh materials was negatively correlated with the sum of (hemi-) cellulose and lignin content.

Likewise, distinct distribution of COD and BMP were found among feedstocks: contribution of the watersoluble phase was $8-69 \%$ to the COD and $7-46 \%$ to the BMP of the raw sample. The highest water-soluble contributions corresponded to the ones of efficient ensiled biomass. Solubilization of organic matter during ensiling was mainly due to the production and accumulation of organic acids from particulate carbohydrates and organic nitrogen. This procedure enabled to compare different strategies or unit operation during the preparation of feedstocks for AD. However, additional methods are required for the identification of the soluble non-biodegradable compounds. In addition, this procedure may be useful to detect and explain kinetic (methane production rate) and biodegradability differences among biomasses before and after pretreatments.

\section{Acknowledgements}

Ruben Teixeira Franco held a doctoral fellowship from the Rhône-Alpes region. This work has been undertaken within the SAM project (Stockage Avant Méthanisation - Storage Before AD) funded by 
ADEME (\# 1506C0038). The authors thank the DEEP laboratory team, including David Lebouil, Hervé Perier-Camby, Nathalie Dumont and Richard Poncet for the given support during the tests. We are grateful to Franck Barra for his permanent availability for discussion and raw material supply. Mathilde Hardier and SUEZ are also acknowledged for the inoculum provided for the BMP tests.

\section{References}

AFNOR, 2016. FD U44-162: Amendements organiques et supports de culture - Caractérisation de la matière organique par fractionnement biochimique et estimation de sa stabilité biologique.

AFNOR, 2002. NF EN 12457-4: Characterization of waste. Leaching - Compliance test for leaching of granular waste materials and sludges.

AFNOR, 1994. NF EN 25663: Qualité de l'eau - Dosage de l'azote Kjeldahl - Méthode après minéralisation au sélénium

Ambye-Jensen, M., Johansen, K.S., Didion, T., Kádár, Z., Schmidt, J.E., Meyer, A.S., 2013. Ensiling as biological pretreatment of grass (Festulolium Hykor): The effect of composition, dry matter, and inocula on cellulose convertibility. Biomass and Bioenergy 58, 303-312. https://doi.org/10.1016/j.biombioe.2013.08.015

Ariunbaatar, J., Panico, A., Esposito, G., Pirozzi, F., Lens, P.N.L., 2014. Pretreatment methods to enhance anaerobic digestion of organic solid waste. Appl. Energy 123, 143-156. https://doi.org/10.1016/j.apenergy.2014.02.035

Batstone, D.J., Keller, J., Angelidaki, I., Kalyuzhnyi, S. V., Pavlostathis, S.G., Rozzi, A., Sanders, W.T., Siegrist, H., Vavilin, V.A., 2002. Anaerobic Digestion Model No.1 (ADM1). IWA Publishing, London. 
Bayard, R., Benbelkacem, H., Gourdon, R., Buffière, P., 2018. Characterization of selected municipal solid waste components to estimate their biodegradability. J. Environ. Manage. 216, 4-12. https://doi.org/10.1016/j.jenvman.2017.04.087

Bayard, R., Liu, X., Benbelkacem, H., Buffiere, P., Gourdon, R., 2016. Can Biomethane Potential (BMP) Be Predicted from Other Variables Such As Biochemical Composition in Lignocellulosic Biomass and Related Organic Residues? Bioenergy Res. 9, 610-623. https://doi.org/10.1007/s12155-0159701-3

Buffière, P., Dooms, M., Hattou, S., Benbelkacem, H., 2018. The hydrolytic stage in high solids temperature phased anaerobic digestion improves the downstream methane production rate. Bioresour. Technol. 259, 111-118. https://doi.org/10.1016/j.biortech.2018.03.037

Buffiere, P., Frederic, S., Marty, B., Delgenes, J.P., 2008. A comprehensive method for organic matter characterization in solid wastes in view of assessing their anaerobic biodegradability. Water Sci. Technol. 58, 1783-1788. https://doi.org/10.2166/wst.2008.517

Buffiere, P., Loisel, D., Bernet, N., Delgenes, J.P., 2006. Towards new indicators for the prediction of solid waste anaerobic digestion properties. Water Sci. Technol. 53, 233-241. https://doi.org/10.2166/wst.2006.254

Buswell, A.M., Mueller, H.F., 1952. Mechanism of Methane Fermentation. Ind. Eng. Chem. 44, 550-552. https://doi.org/10.1021/ie50507a033

Carlsson, M., Lagerkvist, A., Morgan-sagastume, F., 2012. The effects of substrate pre-treatment on anaerobic digestion systems: A review. Waste Manag. 32, 1634-1650. https://doi.org/10.1016/j.wasman.2012.04.016 
Carrere, H., Antonopoulou, G., Affes, R., Passos, F., Battimelli, A., 2016. Review of feedstock pretreatment strategies for improved anaerobic digestion: From lab-scale research to full-scale application. Bioresour. Technol. 199, 386-397. https://doi.org/10.1016/j.biortech.2015.09.007

Chen, J.L., Ortiz, R., Steele, T.W.J., Stuckey, D.C., 2014. Toxicants inhibiting anaerobic digestion: A review. Biotechnol. Adv. 32, 1523-1534. https://doi.org/10.1016/j.biotechadv.2014.10.005

Desta, S.T., Yuan, X., Junfeng, L., Shao, T., 2016. Ensiling Characteristics, structural and nonstructural carbohydrate composition and Enzymatic Digestibility of Napier grass Ensiled with Additives. Bioresour. Technol. https://doi.org/10.1016/j.biortech.2016.09.068

Dewar, W.A., McDonald, P., Whittenbury, R., 1963. The hydrolysis of grass hemicelluloses during ensilage. J. Sci. Food Agric. 14, 411-417. https://doi.org/10.1002/jsfa.2740140610

Elliott, A., Mahmood, T., 2012. Comparison of Mechanical Pretreatment Methods for the Enhancement of Anaerohic Digestion of Pulp and Paper Waste Activated Sludge. Water Environ. Res. 84, 497-506. https://doi.org/10.2175/106143012X13347678384602

Gallegos, D., Wedwitschka, H., Moeller, L., Zehnsdorf, A., Stinner, W., 2017. Effect of particle size reduction and ensiling fermentation on biogas formation and silage quality of wheat straw. Bioresour. Technol. 245, 216-224. https://doi.org/10.1016/j.biortech.2017.08.137

Gonzalez-Estrella, J., Asato, C.M., Jerke, A.C., Stone, J.J., Gilcrease, P.C., 2017. Effect of Structural Carbohydrates and Lignin Content on the Anaerobic Digestion of Paper and Paper Board Materials by Anaerobic Granular Sludge. Biotechnol. Bioeng. 114, 951-960. https://doi.org/10.1002/bit.26228

Hartmann, H., Angelidaki, I., Ahring, B., 2000. Increase of anaerobic degradation of particulate organic matter in full-scale biogas plants by mechanical maceration. Water Sci. Technol. 41, 145-153. 
Hendriks, A.T.W.M., Zeeman, G., 2009. Pretreatments to enhance the digestibility of lignocellulosic biomass. Bioresour. Technol. 100, 10-18. https://doi.org/10.1016/j.biortech.2008.05.027

Holliger, C., Alves, M., Andrade, D., Angelidaki, I., Astals, S., Baier, U., Bougrier, C., Buffiere, P., Carballa, M., de Wilde, V., Ebertseder, F., Fernandez, B., Ficara, E., Fotidis, I., Frigon, J.-C., de Laclos, H.F., Ghasimi, D.S.M., Hack, G., Hartel, M., Heerenklage, J., Horvath, I.S., Jenicek, P., Koch, K., Krautwald, J., Lizasoain, J., Liu, J., Mosberger, L., Nistor, M., Oechsner, H., Oliveira, J. V., Paterson, M., Pauss, A., Pommier, S., Porqueddu, I., Raposo, F., Ribeiro, T., Rusch Pfund, F., Stromberg, S., Torrijos, M., van Eekert, M., van Lier, J., Wedwitschka, H., Wierinck, I., 2016. Towards a standardization of biomethane potential tests. Water Sci. Technol. 74, 2515-2522. https://doi.org/10.2166/wst.2016.336

ISO, 1998. ISO 14235: Soil quality - Determination of organic carbon by sulfochromic oxidation.

ISO, 1995. ISO 11734: Water quality - Evaluation of the "ultimate" anaerobic biodegradability of organic compounds in digested sludge - Method by measurement of the biogas production.

Janke, L., Kathleen, B., Harris, P., Hill, A., Lee, S., Weinrich, S., Marchuk, S., Baillie, C., 2019. Ensiling fermentation reveals pre-treatment e ff ects for anaerobic digestion of sugarcane biomass : An assessment of ensiling additives on methane potential. Bioresour. Technol. https://doi.org/10.1016/j.biortech.2019.01.143

Jeffries, T.W., 1994. Biodegradation of lignin and hemicelluloses. Biochem. Microb. Degrad. 233-277. https://doi.org/10.1007/978-94-011-1687-9_8

Jeffries, T.W., 1990. Biodegradation of lignin-carbohydrate complexes. Biodegradation 1, 163-176. https://doi.org/https://doi.org/10.1007/BF00058834 
Jimenez, J., Aemig, Q., Doussiet, N., Steyer, J., Houot, S., Patureau, D., 2015. A new organic matter fractionation methodology for organic wastes : Bioaccessibility and complexity characterization for treatment $\quad$ optimization. $\quad$ Bioresour. $\quad$ Technol. $\quad$ 194, $344-353$. https://doi.org/10.1016/j.biortech.2015.07.037

Kianmehr, P., Parker, W., Seto, P., 2010. An evaluation of protocols for characterization of ozone impacts on WAS properties and digestibility. Bioresour. Technol. 101, 8565-8572. https://doi.org/10.1016/j.biortech.2010.06.061

Kreuger, E., Nges, I., Björnsson, L., 2011. Ensiling of crops for biogas production: effects on methane yield and total solids determination. Biotechnol. Biofuels 4, 44. https://doi.org/10.1186/1754-6834-4-44

Larsen, S.U., Hjort-Gregersen, K., Vazifehkhoran, A.H., Triolo, J.M., 2017. Co-ensiling of straw with sugar beet leaves increases the methane yield from straw. Bioresour. Technol. 245, 106-115. https://doi.org/10.1016/j.biortech.2017.08.117

Liu, X., Bayard, R., Benbelkacem, H., Buffière, P., Gourdon, R., 2015. Evaluation of the correlations between biodegradability of lignocellulosic feedstocks in anaerobic digestion process and their biochemical characteristics. Biomass and Bioenergy 81, 534-543. https://doi.org/10.1016/j.biombioe.2015.06.021

McDonald, P., Henderson, A.., Heron, S.J.., 1991. The Biochemistry of Silage, Second Edi. ed. Chalcombe Publications, Marlow, Bucks.

Menardo, S., Balsari, P., Tabacco, E., Borreani, G., 2015. Effect of Conservation Time and the Addition of Lactic Acid Bacteria on the Biogas and Methane Production of Corn Stalk Silage. Bioenergy Res. 8, 1810-1823. https://doi.org/10.1007/s12155-015-9637-7 
Montgomery, L.F.R., Bochmann, G., 2014. Pretreatment of feedstock for enhanced biogas production.

Pakarinen, A., Maijala, P., Jaakkola, S., Stoddard, F.L., Kymäläinen, M., Viikari, L., 2011. Evaluation of preservation methods for improving biogas production and enzymatic conversion yields of annual crops. Biotechnol. Biofuels 4, 20. https://doi.org/10.1186/1754-6834-4-20

Patinvoh, R.J., Osadolor, O.A., Chandolias, K., Horváth, I.S., Taherzadeh, M.J., 2017. Innovative pretreatment strategies for biogas production. Bioresour. Technol. 224, 13-24. https://doi.org/10.1016/j.biortech.2016.11.083

Paudel, S.R., Banjara, S.P., Choi, O.K., Park, K.Y., Kim, Y.M., Lee, J.W., 2017. Pretreatment of agricultural biomass for anaerobic digestion: Current state and challenges. Bioresour. Technol. 245, 1194-1205. https://doi.org/10.1016/j.biortech.2017.08.182

Pavlostathis, S.G., Giraldo-Gomez, E., 1991. Kinetics of anaerobic treatment - A critical review. Crit. Rev. Environ. Control 21, 411-490. https://doi.org/10.1080/10643389109388424

Porter, M.G., Murray, R.S., 2001. The volatility of components of grass silage on oven drying and the interrelationship between dry-matter content estimated by different analytical methods. Grass Forage Sci. 56, 405-411. https://doi.org/10.1046/j.1365-2494.2001.00292.x

Schievano, A., Pognani, M., Imporzano, G.D., Adani, F., 2008. Predicting anaerobic biogasification potential of ingestates and digestates of a full-scale biogas plant using chemical and biological parameters. Bioresour. Technol. 99, 8112-8117. https://doi.org/10.1016/j.biortech.2008.03.030

Shin, H.S., Han, S.K., Song, Y.C., Lee, C.Y., 2001. Multi-Step Sequential Batch Two-Phase Anaerobic Composting of Food Waste. Environ. Technol. 22, 271-279. https://doi.org/10.1080/09593332208618283 
Shrestha, S., Fonoll, X., Khanal, S.K., Raskin, L., 2017. Biological strategies for enhanced hydrolysis of lignocellulosic biomass during anaerobic digestion: Current status and future perspectives. Bioresour. Technol. 245, 1245-1257. https://doi.org/10.1016/j.biortech.2017.08.089

Tanaka, S., Kobayashi, T., Kamiyama, K., N, M.L., Bildan, S., 1997. Effects of thermochemical pretreatment on the anaerobic digestion of waste activated sludge. Water Sci. Technol. 35, 209-215. https://doi.org/10.1016/S0273-1223(97)00169-8

Teixeira Franco, R., Buffière, P., Bayard, R., 2018b. Co-ensiling of cattle manure before biogas production: Effects of fermentation stimulants and inhibitors on biomass and methane preservation. Renew. Energy 121, 315-323. https://doi.org/10.1016/j.renene.2018.01.035

Teixeira Franco, R., Buffière, P., Bayard, R., 2018a. Effects of Storage Conditions, Total Solids Content and Silage Additives on Fermentation Profiles and Methane Preservation of Cattle Manure Before Anaerobic Digestion. Waste and Biomass Valorization 9, 2307-2317. https://doi.org/10.1007/s12649-018-0255-4

Teixeira Franco, R., Buffière, P., Bayard, R., 2017a. Optimizing storage of a catch crop before biogas production: impact of ensiling and wilting under unsuitable weather conditions. Biomass and Bioenergy 100, 84-91. https://doi.org/10.1016/j.biombioe.2017.03.017

Teixeira Franco, R., Buffière, P., Bayard, R., 2017b. Cattle manure for biogas production. Does ensiling and wheat straw addition enhance preservation of biomass and methane potential? Biofuels. https://doi.org/10.1080/17597269.2017.1387751

Teixeira Franco, R., Buffière, P., Bayard, R., 2016a. Ensiling for biogas production: Critical parameters. A review. Biomass and Bioenergy 94, 94-104. https://doi.org/10.1016/j.biombioe.2016.08.014 
Teixeira Franco, R., Buffière, P., Bayard, R., 2016b. Optimizing agricultural wastes storage before anaerobic digestion: impact of ensiling on methane potential of lignocellulosic biomass, in: 4th International Conference on Sustainable Solid Waste Management. Limassol, Cyprus.

Triolo, J.M., Pedersen, L., Qu, H., Sommer, S.G., 2012. Biochemical methane potential and anaerobic biodegradability of non-herbaceous and herbaceous phytomass in biogas production. Bioresour. Technol. 125, 226-232. https://doi.org/10.1016/j.biortech.2012.08.079

Triolo, J.M., Sommer, S.G., Møller, H.B., Weisbjerg, M.R., Jiang, X.Y., 2011. A new algorithm to characterize biodegradability of biomass during anaerobic digestion: Influence of lignin concentration on methane production potential. Bioresour. Technol. 102, 9395-9402. https://doi.org/10.1016/j.biortech.2011.07.026

Tsapekos, P., Kougias, P.G., Angelidaki, I., 2015. Anaerobic Mono- and Co-digestion of Mechanically Pretreated Meadow Grass for Biogas Production. Energy Fuels 29, 4005-4010. https://doi.org/10.1021/ef5027949

Van Soest, P.J., Wine, R.H., 1967. Use of detergents in the analysis of fibrous feeds IV. Determination of plant cell-wall constituents. J. Assoc. Off. Anal. Chem. 50, 50-55.

Vavilin, V.A., Rytov, S. V, Lokshina, L.Y., 1996. A description of hydrolysis kinetics in anaerobic degradation of particulate organic matter. Bioresour. Technol. 56, 229-237.

Vervaeren, H., Hostyn, K., Ghekiere, G., Willems, B., 2010. Biological ensilage additives as pretreatment for maize to increase the biogas production. Renew. Energy 35, 2089-2093. https://doi.org/10.1016/j.renene.2010.02.010

Walkley, A., Black, I.A., 1934. An examination of the Degtjareff method for determining soil organic 
matter, and a proposed modification of the chromic acid titration method. Soil Sci. 37, 29-38. https://doi.org/10.1097/00010694-193401000-00003

Ward, A.J., Hobbs, P.J., Holliman, P.J., Jones, D.L., 2008. Optimisation of the anaerobic digestion of $\begin{array}{lllll}\text { agricultural } & \text { resources. } & \text { Bioresour. } & \text { Technol. } & 99,\end{array}$ https://doi.org/10.1016/j.biortech.2008.02.044

Xu, F., Wang, Z., Li, Y., 2014. Predicting the methane yield of lignocellulosic biomass in mesophilic solidstate anaerobic digestion based on feedstock characteristics and process parameters. Bioresour. Technol. 173, 168-176. https://doi.org/10.1016/j.biortech.2014.09.090

Yenigün, O., Demirel, B., 2013. Ammonia inhibition in anaerobic digestion: A review. Process Biochem. 48, 901-911. https://doi.org/10.1016/j.procbio.2013.04.012 